УДК 355.45.02

Фролов В. С. к.військ.н, с.н.с; Саганюк Ф. В. к.ю.н., доцент; Овчаренко С. М.

Центр воєнно-стратегічних досліджень Національного університету оборони України імені Івана Черняховського, Київ

\section{Деякі шляхи розвитку спроможностей військ (сил) для їх застосування у гібридній війні}

Резюме. Стаття присвячена проблемі розвитку спроможностей складових сил оборони та стратегічного керівництва ними для більш ефективної протидії російській агресії.

Ключові слова: спроможності, сили оборони, сектор безпеки і оборони, стратегічне керівництво силами оборони, стратегічне військове управління.

Постановка проблеми. Оборонна реформа, яка впроваджується в Україні, має за мету набуття та підтримання силами оборони необхідного рівня бойової готовності та здатності до виконання завдань оборони держави (оборонних спроможностей) для ефективного реагування на воєнні загрози [1].

Незважаючи на це концептуальне положення, в підсумках реформування Збройних Сил України за 2016 рік значиться, що основні зусилля Міністерства оборони та Генерального штабу зосереджені на виконанні визначеними силами і засобами Збройних Сил України завдань в антитерористичній операції, збалансуванні структури, складу i чисельності органів військового управління та Збройних Сил, нарощуванні боєздатності військ (сил), їх всебічному забезпеченні, а також створенні нормативно-правового підгрунтя подальшого розвитку Збройних Сил [2].

Між тим, дієвими шляхами набуття оборонних спроможностей військами (силами) визнаються не тільки вдосконалення основ застосування військ (сил), органів військового управління та військових частин, а й впровадження нових форм та методів ведення операцій і бойових дій, покращення системи відбору, навчання та підготовки особового складу [3].

Основними дороговказами у цій сфері можна вважати не тільки Стратегію національної безпеки України та Воєнну доктрину, Концепцію розвитку сектору безпеки i оборони, Стратегічний оборонний бюлетень, Державні програми розвитку озброєння та Збройних Сил України, про які йдеться там само у [2], а і План дій щодо впровадження оборонної реформи у $2016-2020$ роках (Дорожня карта оборонної реформи), щоправда, затверджений Міністром оборони України, а не Президентом України; Річну національну програму під егідою Комісії Україна-НАТО на 2017 рік; Рекомендації 3 оборонного планування на основі спроможностей в Міністерстві оборони України та Збройних Силах України, затверджені Міністром оборони України 12 червня 2017 року та деякі інші.

Нерозв'язаною сучасною проблемою тут залишається відсутність об'єднаного стратегічного керівництва силами оборони, яке визнано найпершою стратегічною ціллю оборонної реформи для наближення до зазначених вище принципів і стандартів НАТО [1].

Не менш суттєвою визначеною там само ціллю оборонної реформи $\epsilon$ розвиток оперативних (бойові, спеціальні) спроможностей сил оборони, а не лише Збройних Сил, необхідних для гарантованої відсічі збройній агресії і оборони держави [1].

Важливою проблемою тут також залишається, планування розвитку складових сил оборони на основі спроможностей для ефективнішого застосування в умовах російської агресії.

Аналіз останніх досліджень i публікацій. Проблема переходу до нового формату протидії агресору та розвитку для цього необхідних військам (силам) оборонних спроможностей для ефективного їх застосування в умовах гібридної агресії РФ $\epsilon$ новою. У сучасній літературі, в тому числі й фаховій військовій, вона недостатньо досліджена і потребує детальнішого вивчення, обговорення та досконалішого унормування.

Метою статті $\epsilon$ пошук та обгрунтування деяких підходів до розв'язання цих проблем у секторі безпеки i оборони України шляхом більш плідного розвитку спроможностей сил оборони, переходу до нового формату стратегічного керівництва ними та протидії агресору.

Виклад основного матеріалу. Реалізація положень зазначених концептуальних документів вважається запорукою досягнення очікуваного результату від впровадження оборонної реформи щодо створення за принципами та стандартами, прийнятими в 
державах-членах НАТО, ефективних, мобільних, оснащених сучасним озброєнням, військовою і спеціальною технікою сил оборони зразка 2020 року, здатних гарантовано забезпечити оборону держави та адекватно і гнучко реагувати на воєнні загрози національній безпеці України, раціонально використовуючи при цьому наявний потенціал (спроможності) та ресурси [1].

Але завдання України полягає не тільки в удосконаленні доктринальної чи концептуальної бази, як рекомендується Міністерством оборони у [4, п. 2.1], а й у розвитку інших базових складових компонентів таких спроможностей. Тут варто звернути увагу на те, що у державах-членах НАТО наряду 3 цим основна увага в зазначеному процесі приділяється не етапам визначення засад державної політики чи потреб у спроможностях військ (сил) та їх розподілу, як зазначається фахівцями МО України у статті [3, с. 6-7], а розвитку певних базових складових компонентів таких спроможностей, які у більшості цих держав майже ідентичні (табл. 1 наведено за: [5, с.49]).

Складові оперативних спроможностей у ЗС зарубіжних країн

\begin{tabular}{|c|c|c|c|c|c|}
\hline $\begin{array}{c}\text { Складові компоненти } \\
\text { спроможностей }\end{array}$ & США & Канада & $\begin{array}{l}\text { Велико- } \\
\text { британія }\end{array}$ & Австралія & Болгарія \\
\hline Доктрина, концепція & + & + & + & & + \\
\hline Командування і управління & + & + & & + & + \\
\hline Організація & + & + & + & + & \\
\hline Колективна підготовка & + & + & + & + & + \\
\hline Взаємосумісність (interoperability) & + & & & & + \\
\hline Інфраструктура & + & + & + & + & + \\
\hline Інформація & & + & + & & \\
\hline Системи озброєння & + & + & + & + & \\
\hline Персонал & + & + & + & + & + \\
\hline Логістика & & + & + & + & + \\
\hline "'Дослідження & & + & & & \\
\hline
\end{tabular}

Тут, зокрема, варто приділити увагу створенню нового формату системи стратегічного керівництва силами оборони: стратегічного військового управління та об'єднаної системи стратегічного керівництва силами оборони, тобто командуванню і управлінню.

Розглядаючи згадані два основні компоненти (складові) спроможностей сил оборони (стратегічне керівництво силами оборони та стратегічне військове управління) необхідно у першу чергу розмежувати їх. У законодавстві ці поняття не конкретизовані та не розмежовані. Очевидним тут $\epsilon$ те, що об' єктом стратегічного військового управління мають бути сили оборони в цілому, а не лише Збройні Сили (3С).

При цьому потрібно враховувати, що однією 3 основних умов створення системи оборони за принципами та стандартами НАТО має бути відновлення Об'єднаного оперативного командування (ООК) як органу управління оперативно-стратегічним угрупованням військ, а також армійських корпусів як оперативно-тактичних об'єднань.

Головнокомандувач Збройних Сил має очолювати стратегічне військове управління усіма силами оборони. Йому мають бути безпосередньо підпорядковані Командувач
ООК, Командувачі видами ЗС, ВДВ та ССО. Командувач ООК через ООШ має здійснювати управління угрупованням Збройних Сил, що призначатимуться для оборони держави в цілому.

За досвідом ведення війн та воєнних конфліктів, у тому числі у форматі АТО, для безпосереднього управління силами оборони доцільно створити Головний итаб Головнокомандувача Збройних Сил.

У державах-членах НАТО базову основу організації військового управління армій складає Об'єднаний штаб (Joint staff).

Аналіз характеру воєнних загроз та новітніх методів підготовки й ведення гібридних війн, а також досвід ведення бойових дій в АТО підтверджують потребу інтеграції управлінських зусиль керівництва в усіх сферах безпеки і оборони України в об'єднану систему стратегічного керівництва сектором безпеки $i$ оборони нового формату для сучасних умов й потреб. Такий підхід відповідатиме базовим принципам НАТО щодо розподілу та делегування відповідальності під час формування й реалізації рішень в усій системі управління - від воєнно-політичного керівництва до окремого підрозділу.

Зарубіжний досвід вирішення аналогічних проблем й досвід ведення бойових 
дій в АТО підтверджують недостатню готовність складових сектору безпеки i оборони України, у тому числі його стратегічного керівництва та сил оборони адекватно протидіяти російській агресії. Помилкове небачення в минулому загроз війни 3 боку РФ зневілювало необхідність створення оперативно-стратегічних та мобільних оперативно-тактичних угруповань військ, що стало основним аргументом для організації оборони України за територіальним принципом, а саме силами бригад у складі Оперативних Командувань (OK).

Основою для формування зазначених спроможностей військ (сил) мають бути вимоги до підготовки та застосування органів військового управління, видів/родів військ (сил) та їх всебічного забезпечення, що визначені відповідними керівними нормативними (доктринальними або концептуальними) документами (бойовими статутами, настановами, керівництвами, положеннями тощо), а також відповідними стандартами HATO (Allied Forces Standards), зокрема:

- загальні вимоги до сил (AFS Vol. I General force standards);

- для сухопутних військ (AFS Vol. II Standards for Land Forces);

- для повітряних сил (AFS Vol. III Standards for Air Forces);

- для військово-морських сил (AFS Vol. IV - Standards for Maritime Forces);

- для об'єднаних штабів (AFS Vol. V Joint Headquarters);

- для сил спеціальних операцій (AFS Vol. $X$ - Standards for Special Operations Forces). Такі рекомендації надані Міністерством оборони України у [4, п. 2.7].

Тут допускається також застосування базових стандартів, визначених керівними документами Міністерства оборони, Збройних Сил, а також НATO (Allied Joint Publications, Allied Publications, Allied Tactical Publications), які $є$ доцільними для впровадження в Україні [4].

Враховуючи позитивний досвід державчленів НАТО, основним консолідуючим базовим органом стратегічного керівництва сектором безпеки і оборони України може бути Рада начіональної безпеки $і$ оборони Украӥни, щоправда за умови уточнення у ззаконодавчому порядку іiі функцій та організаційно-штатної структури. Основними іiі функціями у цій сфері відповідно до ст. 107 Конституції України можуть бути: оцінка воєнно-політичної, економічної, інформаційної, криміногенної й іншої обстановки та іiі впливу на безпеку і оборону держави;

визначення загроз національній безпеці в усіх сферах життєдіяльності держави;

обгрунтування стратегічних цілей, мети та основних напрямів і завдань по усіх сферах функціонування держави щодо протидії гібридній агресії противника;

формування комплексних програм протидії агресору на кожному етапі підготовки та ведення гібридної агресії противника;

розроблення проектів необхідних законодавчих та інших нормативно-правових актів щодо оборони держави та підготовка їх для подання їх встановленим порядком до Верховної Ради України;

координація та контроль органів виконавчої влади, а в особливий період $\mathrm{i}$ приватного бізнесу, у сфері національної безпеки і оборони тощо.

Для досягнення очікуваного результату оборонної реформи 3 питань розвитку необхідних оперативних спроможностей військ (сил) потрібно розвивати й інші їх компоненти (складові), вказані у табл. 1. Зокрема, особливої уваги тут потребує планування та спільна підготовка військ (сил). Для цього Генеральним штабом 3С України, як рекомендовано Міністерством оборони, має розроблятися "комплексний документ 3 розвитку спроможностей Збройних Сил”, який затверджується Міністром оборони України $[4$, п. 5.12, 5.14]. Це відповідає i вимогам Концепції розвитку сектору безпеки і оборони України, якою МО України визначено відповідальним серед складових сектору безпеки і оборони України за організацію планування, реагування на загрози та під час виконання ними завдань за призначенням, що обгрунтовується авторами в окремій монографії [6].

Як зазначається там само у рекомендаціях MO [4, п. 5.14], такий комплексний документ має розроблятися 3 урахуванням:

ризиків та загроз воєнного характеру, що впливають на рівень воєнної безпеки і оборони; сценаріїв розвитку кризових ситуацій; концептуальних документів щодо застосування Збройних Сил у майбутньому безпековому середовищі;

обсягу завдань, форм, способів та масштабів їх застосування за уточненими сценаріями; 
параметрів їх перспективної

організаційної структури;

потреб для досягнення такої структури;

обсягів прогнозованого ресурсного

забезпечення;

етапів досягнення необхідних

спроможностей за всіма базовими компонентами (складовими) тощо.

Представляється, що наведені вимоги мають відноситись не тільки до Збройних Сил, а і до інших складових сил оборони. А комплексним їх документом 3 наведених у Концепції розвитку сектору безпеки і оборони України, на нашу думку, могло би бути, наприклад, Положення про організацію та здійснення стратегічного планування, яке має затверджуватись Президентом України i застосовуватись усіма складовими сил оборони.

Суттєвим у цій системі має бути також розвиток воєнної освіти i науки, вдосконалення навчальних програм і належна підготовка особового складу, не тільки "компетенцій", а компетентних військових фахівців за усіма фаховими напрямами i потребами військ (сил).

У цьому напрямі може слугувати i зарубіжний досвід. Зокрема, у США нещодавно оприлюднено Посібник рекомендацій щодо російської військової агресії нового покоління (Asymmetric Warfare Group Russian New Generation Warfare Handbook) [7]. Посібник призначений для підвищення інформованості американських військових про тактику Росії у гібридній війні проти України та як їй протидіяти. Тут також наведені слушні рекомендації для американських батальйонів та бригадних бойових груп щодо боротьби 3 російськими методами війни i наголошується, що американські солдати повинні робити те саме, бо, як акцентується у посібнику: “Тільки дурні вчаться на своїх помилках. Мудра людина вчиться на помилках інших"[7].

\section{Висновки}

1. Воєнно-політична та воєнностратегічна обстановка, що складається навколо України, вимагає перебудови оборони України на всіх рівнях оперативного мистецтва.

Масштаби сучасних воєнних загроз Україні 3 боку РФ вимагають приведення системи оборони держави до вимог воєнного мистецтва та світового досвіду. Створення оперативно-стратегічного угруповання військ сил оборони на південному сході України під єдиним керівництвом ООК стає нагальною необхідністю та єдиним варіантом організованого опору можливому вторгненню угруповань військ (сил) Західного та Південного військових округів Росії.

2. Пріоритетом у застосуванні сил оборони в умовах гібридної агресії з боку Росії залишається комплексне планування розвитку необхідних їм спроможностей та спільної підготовки до відбиття агресії основних угруповань військ (сил) противника, що загрожують територіальній цілісності України.

3. Воєнно-стратегічна ситуація, способи та методи ведення Російською Федерацією гібридної агресії проти України, потребують створення мобільних оперативно-тактичних угруповань у складі армійських корпусів для забезпечення формування у короткі терміни оперативно-стратегічного угруповання військ (сил) Збройних Сил України та інших складових сил оборони на території південносхідних областей держави.

Напрям подальших досліджень. Для розв’язання окресленої проблеми необхідно вдосконалити чинне законодавство щодо сектору безпеки і оборони, визначити у ньому усі складові сил оборони та їх функції в цьому секторі, порядок взаємодії та застосування у передбачених законом випадках i порядок стратегічного планування розвитку необхідних їм спроможностей (кожного компонента) для забезпечення ефективнішого виконання покладених на них завдань щодо оборони держави від агресора.

\section{ПЕРЕЛІК ВИКОРИСТАНОЇ ЛІТЕРАТУРИ}

1. План дій щодо впровадження оборонної реформи у 2016-2020 роках (Дорожня карта оборонної реформи): затв. МО України 15.08.16.

2. Біла книга - 2016. Збройні Сили України: К., 2017. $112 \mathrm{c}$.

3. Руснак I. C., Петренко А. Г., Я Яковенко А. В., Романюк I. М. Оборонне планування на основі спроможностей: особливості та перспективи впровадження. Наука і оборона. 2017. № 2. С.3-10.

4. Рекомендації з оборонного планування на основі спроможностей в Міністерстві оборони України та Збройних Сил України: затв. МО України 12.06.17.

5. Удосконалення процесу оборонного та бюджетного планування. Збірник матеріалів науково-практичного семінару (26.11.2009). К.: НУОУ, 2010. 92 c.

6. Сектор безпеки i оборони України: теорія, стратегія, практика. Монографія / Саганюк Ф. В., Фролов В. С., Устименко О. В., Лобко М. М. та ін. K., 2017. $180 \mathrm{c}$.

7. Asymmetric Warfare Group. Russian New Generation Warfare Handbook. URL: Режим доступу: https://publicintelligence.net/awg-russiannew-warfare- handbook. 
Фролов В. С. к.воен.н, с.н.с.;

Саганюк Ф. В., к.ю.н., доцент;

Овчаренко С. М.

Центр военно-стратегических исследований Национального университета обороны Украины имени Ивана Черняховского, Киев

Некоторые пути развития возможностей войск (сил) для их применения в гибридной войне

Резюме. Статья посвящена проблеме развития возможностей составляющих сил обороны и стратегического руководства ими для эффективного противодействия российской агрессии.

Ключевые слова: возможности, силы обороны, сектор безопасности и обороны, стратегическое управление силами обороны, стратегическое военное управление.

V. Frolov, Ph.D, senior researcher;

F. Sahaniuk, Ph.D, assistant professor;

S. Ovcharenko

Center for Military and Strategic Studies of the National Defence University of Ukraine named after Ivan Cherniakhovskyi, Kyiv

Some ways to develop the capabilities of the forces (forces) for their use in the hybrid war

Resume. The article is devoted to the problem of the development of capabilities of the forces of defense and strategic direction for more effective counteraction to Russian aggression.

Keywords: capabilities, defense, security and defense, strategic defense, strategic military management. 